REFLEKSI HUKUM

Jurnal Imu Hukum
p-ISSN 2541-4984 | e-ISSN 2541-5417

Volume 6 Nomor 1, Oktober 2021, Halaman 53-70

DOI: https:// doi.org/10.24246/jrh.2021.v6.i1.p53-70

Open access at: http:// ejournal.uksw.edu/refleksihukum

Penerbit: Fakultas Hukum Universitas Kristen Satya Wacana

\title{
DIVIDEN PERSEROAN TERBATAS YANG TIDAK DIBAGIKAN KEPADA PEMEGANG SAHAM SEBAGAI UTANG DALAM KEPAILITAN
}

\author{
Devi Andani \\ Fakultas Hukum Universitas Janabadra|devi_andani@janabadra.ac.id
}

A R T I C L E I N F O
Article history:
Received
31 Maret 2021
Revised
15 Juni 2021
Accepted
25 November 2021
Kata-kata Kunci:
Kepailitan; Utang;
Dividen; Pemegang
saham; Perseroan
terbatas.

Keywords:
Bankruptcy; Debt;
Dividends;
Shareholders; Limited
Liability company.

\section{Abstrak}

Tulisan ini ingin membahas dividen perseroan terbatas yang tidak dibagikan kepada pemegang saham sebagai utang dalam kepailitan. Persoalannya berkenaan dengan apakah dividen perseroan terbatas yang tidak dibagikan kepada pemegang saham sebagai utang dalam kepailitan, serta akibat hukum dividen perseroan terbatas yang tidak dibagikan kepada pemegang saham dalam kepailitan. Hasil studi menunjukkan bahwa dividen perseroan terbatas yang belum dibagikan kepada pemegang saham dapat dianggap sebagai utang perseroan, yang mana utang tersebut dapat ditagihkan ke perseroan. Akibatnya adalah perseroan yang belum membagikan dividen kepada para pemegang saham dapat dipailitkan oleh pemegang saham dengan berlandaskan pada dividen yang dianggap sebagai utang.

\begin{abstract}
This article aims to analyze the limited liability company dividends that are not distributed to shareholders as debt in bankruptcy by focusing on its legal consequences. The article shows that the limited liability company dividends that are not distributed to shareholders yet can be considered as the company's debt, meaning the debt can be collected from the company. As a result, a company that has not distributed dividends to shareholders can be bankrupt by the shareholders based on dividends which are considered debt.
\end{abstract}




\section{PENDAHULUAN}

Permohonan pailit dapat diajukan oleh debitor sendiri, seorang atau lebih kreditor, dan kejaksaan untuk kepentingan umum. Dalam hal menyangkut debitor merupakan bank, permohonan pernyataan pailit hanya dapat diajukan oleh Bank Indonesia. Kemudian, dalam hal menyangkut debitor yang merupakan perusahaan efek, lembaga kliring dan penjaminan, dan lembaga penyimpanan dan penyelesaian permohonan pernyataan pailitnya, hanya dapat diajukan oleh Badan Pengawas Pasar Modal (Bapepam). Selanjutnya, dalam hal menyangkut debitor yang merupakan perusahaan asuransi, perusahaan reasuransi, dana pensiun, badan usaha milik negara yang bergerak di bidang kepentingan publik hanya dapat diajukan oleh Menteri Keuangan. ${ }^{1}$

Terbitnya Undang-Undang Nomor 21 Tahun 2011 tentang Otoritas Jasa Keuangan (selanjutnya disebut UU OJK) kewenangan Bank Indonesia, Bapepam, dan Menteri keuangan dalam hal mengajukan permohonan pailit beralih kepada Otoritas Jasa Keuangan (OJK) sebagai lembaga yang independen dan bebas dari campur tangan pihak lain, yang mempunyai fungsi, tugas, dan wewenang pengaturan, pengawasan, pemeriksaan, dan penyidikan. ${ }^{2}$ Setelah pengajuan pailit diajukan oleh debitor, seorang atau lebih kreditor, kejaksaan, atau OJK, maka pengadilan yang memiliki kompetensi untuk memutuskan permohonan pernyataan pailit adalah Pengadilan Niaga. Pengadilan Niaga merupakan bagian dari Pengadilan Negeri, tetapi tidak semua Pengadilan Negeri mempunyai Pengadilan Niaga. Sampai saat ini terdapat lima Pengadilan Niaga, yaitu di Jakarta Pusat, Medan, Semarang, Surabaya, dan Makasar.

Pada prinsipnya, pengaturan masalah kepailitan merupakan suatu perwujudan dari Pasal 1131 dan Pasal 1132 Kitab Undang-Undang Hukum Perdata (KUH Perdata). Dalam Pasal 1131 dinyatakan "Segala kebendaan si berutang, baik yang bergerak maupun yang tidak bergerak, baik yang sudah ada maupun yang baru ada di kemudian hari menjadi tanggungan untuk segala perikatan perorangan". ${ }^{3}$ Selanjutnya dalam Pasal 1132 ditegaskan bahwa "Kebendaan tersebut menjadi jaminan bersama-sama bagi semua orang yang mengutangkan padanya; pendapatan penjualan benda-benda itu dibagi menurut keseimbangan, yaitu menurut besar-kecilnya piutang masing-masing, kecuali apabila di antara para berpiutang itu ada alasan-alasan yang sah untuk didahulukan". ${ }^{4}$

Undang-Undang Nomor 37 Tahun 2004 tentang Kepailitan dan Penundaan Kewajiban Pembayaran Utang (selanjutnya disebut UU Kepailitan dan PKPU) menggunakan prinsip Pari Passu Prorata Parte yang mempunyai makna bahwa harta kekayaan debitor menjadi jaminan bersama bagi semua kreditor. Hasil penjualannya harus dibagikan secara proporsional (prorata) antara mereka, kecuali jika antara para kreditor ada yang harus didahulukan untuk menerima pembayaran tagihannya berdasarkan alasan yang sah menurut undang-undang.

Lihat Pasal 2 ayat (2), (3), (4), dan (5) Undang-Undang Nomor 37 Tahun 2004 tentang Kepailitan dan PKPU.

Lihat UU OJK

Lihat Pasal 1131 KUH Perdata.

Lihat Pasal 1132 KUH Perdata. 
Prinsip ini memberikan pembagian yang adil secara proporsional bagi setiap kreditor. Apabila debitor telah dinyatakan pailit, maka pengurusan dan pemberesan harta pailit akan dilakukan oleh Kurator dengan pengawasan Hakim Pengawas. Hakim Pengawas adalah Hakim yang bertugas melakukan pengawasan terhadap tindakan kurator dalam melakukan pemberesan harta pailit yang diangkat melalui putusan perkara kepailitan. Sedangkan Kurator adalah pihak yang akan menangani seluruh kegiatan pemberesan termasuk pengurusan harta pailit. 5 Peran kurator adalah bertindak sebagai penyelesaian masalah kepailitan yang dialami oleh debitur, dimana kurator tidak bertindak untuk kepentingan pemohon, melainkan untuk kepentingan boedel pailit. Hal ini berarti bahwa peran kurator tidak melulu lebih mendahulukan kepentingan kreditur, tetapi harus fair juga terhadap debitur selaku yang mengalami kepailitan. ${ }^{6}$ Meskipun debitor kehilangan hak untuk mengurus dan menguasai harta kekayaannya tetapi debitor tidak kehilangan kecakapan untuk melakukan perbuatan hukum tersebut sepanjang perbuatan hukum tersebut tidak mempunyai akibat hukum atas harta kekayaannya yang telah dikuasai kurator. ${ }^{7}$

Pada asasnya setiap utang wajib dibayar. Ketentuan ini berlaku secara universal, kecuali jika utang tersebut terjadi karena perbuatan melawan hukum. Seperti utang yang terjadi karena perjudian; utang karena jual beli barang terlarang, misalnya narkoba; utang yang timbul karena jual beli manusia (human trafficking); dan utang-utang lainnya yang terjadi karena melawan hukum. ${ }^{8}$ Tidak terkecuali jika perseroan terbatas memiliki utang, maka wajib membayar utang tersebut.

Perseroan terbatas mempunyai kewajiban memberikan laba kepada pemegang saham dalam bentuk dividen. Pemegang saham perseroan terbatas mendapatkan dividen, yaitu pendistribusian laba kepada pemegang saham secara pro rata. Pada prinsipnya dibayarkan dalam bentuk uang. Akan tetapi, dimungkinkan juga dalam bentuk script atau surat saham sementara maupun produk atau property perusahaan. ${ }^{9}$ Berdasarkan Pasal 71 ayat (2) Undang-Undang Nomor 40 Tahun 2007 tentang Perseroan Terbatas (Selanjutnya disebut UUPT), dividen yang dapat dibagikan kepada pemegang saham adalah seluruh laba bersih setelah dikurangi penyisihan untuk cadangan kecuali ditentukan lain dalam Rapat Umum Pemegang Saham (RUPS). Jika perseroan terbatas tidak membayarkan dividen kepada pemegang saham, hal ini akan menjadi permasalahan. Sehingga rumusan masalah yang akan dijawab dan dibahas yaitu: pertama, apakah dividen perseroan terbatas yang tidak dibagikan kepada pemegang saham sebagai utang dalam kepailitan? Kedua, bagaimana akibat hukum dividen perseroan terbatas yang tidak dibagikan kepada pemegang saham dalam kepailitan?

Purbandari, 'Tanggung Jawab Hukum Perseroan Terbatas (PT) yang Dinyatakan Pailit' (2014) 1 (1) E-Journal Widya Yustisia 29, 34.

Rumelda Silalahi dan Onan Purba, 'Peran dan Wewenang Kurator dalam Kepailitan Perseroan Terbatas' (2020) 1 (2) Jurnal Retenrum 119, 121.

$7 \quad$ Pita Permatasari, 'Perlindungan Hukum Pemegang Saham Minoritas Perusahaan Terbuka Akibat Putusan Pailit' (2014) 1 (2) Salam; Jurnal Filsafat dan Budaya Hukum 295, 301.

Syamsudin Sinaga, Hukum Kepailitan Indonesia (cet.1, Tata Nusa 2012) 43.

M. Yahya Harahap, Hukum Perseroan Terbatas (cet. 1, Sinar Grafika 2016) 291. 


\section{PEMBAHASAN}

\section{Dividen Perseroan Terbatas yang Tidak Dibagikan Kepada Pemegang Saham Sebagai Utang dalam Kepailitan}

Dividen merupakan hak pemegang saham biasa (common stock) untuk mendapatkan bagian dari keuntungan perusahaan. Jika perusahaan memutuskan untuk membagi keuntungan dalam dividen, semua pemegang saham biasa mendapatkan haknya yang sama. Ketika sebuah perusahaan memperoleh laba bersih pada suatu periode tertentu, manajemen akan dihadapkan pada keputusan pemanfaatan laba tersebut. Dua alternatif penggunaan utama laba adalah dibagikan sebagai dividen atau ditahan sebagai laba ditahan (retained earning). Keputusan inilah yang dikenal sebagai kebijakan dividen yaitu menentukan seberapa besar proporsi laba yang akan dibagikan sebagai dividen. ${ }^{10}$ Dividen dapat dikatakan memiliki peranan penting karena melalui dividen perusahaan dapat memperoleh dana yang berasal dari para investor yang digunakan perusahaan untuk pertumbuhan dan kelangsungan hidup perusahaan. ${ }^{11}$ Dividen merupakan laba bersih perusahaan yang sebagian dibagikan kepada pemegang saham berdasarkan dengan proporsi kepemilikan saham yang dimiliki. Besaran nilai dan waktu pembayaran dividen berdasarkan pada RUPS. ${ }^{12}$ Dividen yang dibagikan perusahaan dapat berupa dividen tunai, artinya kepada setiap pemegang saham diberikan dividen berupa tunai dalam jumlah rupiah tertentu untuk setiap saham atau dapat pula berupa dividen saham berarti kepada setiap pemegang saham diberikan dividen sejumlah saham sehingga jumlah saham yang dimiliki seorang pemodal akan bertambah dengan adanya pembagian dividen saham tersebut. 13

Kebijakan dividen adalah penentuan berapakah jumlah laba yang harus diberikan kepada pemegang saham dan jumlah laba ditahan yang akan digunakan untuk investasi perusahaan. ${ }^{14}$ Kebijakan dividen menjadi suatu pertimbangan yang dilematis karena terdapat adanya konflik kepentingan. Pihak manajemen umumnya menahan kas untuk berinvestasi agar dapat meningkatkan pertumbuhan perusahaan. Di pihak lain, pemegang saham menginginkan dividen yang besar atas kepemilikan sahamnya.15 Dengan perkataan lain, kebijakan dividen menyediakan informasi mengenai performa (performance) perusahaan. Oleh karena itu, masing-masing perusahaan menetapkan kebijakan dividen yang berbeda-beda, karena kebijakan dividen berpengaruh terhadap nilai perusahaan dalam membayar dividen kepada para pemegang sahamnya, maka perusahaan

Setia Mulyawan, Manajemen Keuangan (cet. 1, Pustaka Setia 2015) 43.

Nicken Destriana, 'Analisis Empiris Faktor-Faktor yang Mempengaruhi Kebijakan Dividen' (2016) 18 (1) Jurnal Bisnis dan Akuntansi 53, 54.

12 Yuli Chomsatu Samrotun, 'Kebijakan Dividen dan Faktor-Faktor yang Mempengaruhinya' (2015) 13 (1) Jurnal Paradigma 92, 93.

13 Retno MEL dan Putri Permatasari, 'Studi Terhadap Pembagian Dividen dan Dampaknya terhadap Harga Saham Perusahaan-Perusahaan yang Terdaftar di Bursa Efek Indonesia Periode 2011-2014' (2016) 2 (1) Jurnal Ilmiah Akuntansi Fakultas Ekonomi 69, 71.

14 Ratna Damayanti, Fithri Setya Marwati, dan Rochmi Widayanti, 'Analisa Kebijakan Dividen Berdasarkan Teori Lintner' (2017) 1 (2) Agregat: Jurnal Ekonomi dan Bisnis 183, 184.

15 AA Ayu Mirah Vathina Devi, I Made Sadha Suardikha, dan I Gusti Ayu nyoman Budiasih, 'Pengaruh Profitabilitas Pada Kebijakan Dividen dengan Likuiditas dan Kepemilikan Manajerial Sebagai Variabel Pemoderasi' (2014) 3 (12) E-Jurnal Ekonomi dan Bisnis Universitas Udayana $702,703$. 
mungkin tidak dapat mempertahankan dana yang cukup untuk membiayai pertumbuhannya di masa mendatang. 16

Menurut Sartono, kebijakan dividen adalah keputusan apakah laba yang diperoleh perusahaan akan dibagikan kepada pemegang saham sebagai dividen atau akan ditahan, dalam bentuk laba ditahan guna pembiayaan investasi dimasa datang. ${ }^{17}$ Sedangkan menurut Riyanto, kebijakan dividen adalah kebijakan yang bersangkutan dengan penentuan pembagian pendapatan (earning) antara pengguna pendapatan untuk dibayarkan kepada para pemegang saham sebagai dividen atau untuk digunakan dalam perusahaan, yang berarti pendapatan tersebut harus ditanam di dalam perusahaan. ${ }^{18} \mathrm{Hal}$ ini menunjukkan bahwa keputusan kebijakan dividen sangat dipengaruhi oleh kondisi keuangan perusahaan. Kemampuan perusahaan membagikan dividen tergantung dari faktorfaktor keuangan perusahaan. ${ }^{19}$ Pembagian dividen merupakan satu hal yang dinantikan oleh pemegang saham. Pembagian dividen dapat dilakukan secara kuartalan ataupun tahunan, tergantung kebijaksanaan yang ditetapkan oleh masing-masing perusahaan. Adapun prosedur pembagian dividen yang aktual menurut Brigham dan Houston adalah (a).Tanggal Pengumuman (Declaration Date), (b) Tanggal Pencatatan Pemegang Saham (Holder of Record Date), (c) lama menerima cek dividen, (d) Tanggal Ex-Dividend (Exdividend Date), (e) Tanggal Pembayaran Dividen (Dividend Payment). ${ }^{20}$

Terdapat beberapa jenis dividen yang dapat dibayarkan kepada para pemegang saham, tergantung pada posisi dan kemampuan perusahaan bersangkutan. Berikut ini adalah jenis-jenis dividen menurut Brigham: ${ }^{21}$

1) Cash Dividend (dividen tunai)

Cash dividend adalah dividen yang dibayarkan dalam bentuk uang tunai. Pada umumnya cash dividend lebih disukai oleh para pemegang saham dan lebih sering dipakai perseroan jika dibandingkan dengan jenis dividen yang lain.

2) Stock Dividend (dividen saham)

Stock dividend adalah dividen yang dibayarkan dalam bentuk saham, bukan dalam bentuk uang tunai. Pembayaran stock dividend juga harus disarankan adanya laba atau surplus yang tersedia, dengan adanya pembayaran dividen saham ini maka jumlah saham yang beredar meningkat, namun pembayaran dividen saham ini tidak akan merubah posisi likuiditas perusahaan karena yang dibayarkan oleh perusahaan bukan merupakan bagian dari arus kas perusahaan.

16 Nurmila Dewi, 'Penentuan Kebijakan Dividen (Dividend Policy) Dalam Praktik Perusahaan' (2010) 7 (1) Jurnal Ekonomi dan Bisnis 1.

17 Sartono Agus, Manajemen Keuangan Teori dan Aplikasi (ed. 4, BPFE 2008) 35.

18 Ibid.

19 M.Y. Dedi Haryanto, 'Pengaruh Faktor-Faktor Keuangan Perusahaan Terhadap Kebijakan Dividen' (2015) 5 (1) Jurnal Ekonomi \& Pembangunan Optimum 95, 96.

20 Brigham dan Houston, terdapat dalam Megawati dan Rahmi Oktanina, 'Pengaruh Pengumuman Dividen Terhadap Abnormal Return Saham Sebelum dan Sesudah Ex-Dividen Pada Perusahaan yang Terdaftar di BEI' (2015) 4 (2) Jurnal Kajian Manajemen Bisnis 8.

21 E..F. Brigham dan J.F. Houston, Dasar-dasar Manajemen Keuangan (ed. 10, Salemba Empat 2006) 66. 
3) Property dividend (dividen barang)

Property dividend adalah dividen yang dibayarkan dalam bentuk barang (aktiva selain kas). Property dividend yang dibagikan ini haruslah merupakan barang yang dapat dibagi-bagi atau bagian-bagian yang homogeny serta penyerahannya kepada pemegang saham tidak akan mengganggu kontinuitas perusahaan.

4) Scrip Dividend

Scrip dividend adalah dividen yang dibayarkan dalam bentuk surat (scrip) janji utang. Perseroan akan membayar sejumlah tertentu dan pada waktu tertentu, sesuai dengan yang tercantum dalam scrip tersebut. Pembayaran dalam bentuk ini akan menyebabkan perseroan mempunyai utang jangka pendek kepada pemegang scrip.

5) Liquidating dividend

Liquidating dividend adalah dividen yang dibagikan berdasarkan pengurangan modal perusahaan, bukan berdasarkan keuntungan yang diperoleh perusahaan.

Selain faktor dividen terdapat utang yang cukup berpengaruh terhadap nilai perusahaan. Utang adalah instrumen yang sangat sensitif terhadap perubahan nilai perusahaan dengan menggunakan debt equity ratio yaitu berfungsi untuk mengetahui setiap rupiah modal sendiri yang dijadikan jaminan utang dalam membiayai kegiatan operasional. Modal yang dimiliki perusahaan akan berpengaruh kepada kebijakan dividen yang sangat bergantung pada modal dalam bentuk laba ditahan. ${ }^{22}$ Pemegang saham yang dirugikan karena tidak menerima pembayaran dividen hingga melewati batas waktu dapat meminta kepada perseroan terbatas untuk dilaksanakan RUPS. Fungsi pelaksanaan RUPS tersebut adalah untuk membahas laporan tahunan perseroan terbatas. Sesuai ketentuan Pasal 66 ayat (2) dan ayat (3) UUPT salah satu isi laporan tahunan adalah laporan keuangan yang harus dibuat sesuai dengan standar akuntansi keuangan. Laporan keuangan disampaikan agar para peserta rapat dapat mengetahui kondisi keuangan perseroan terbatas. Jika laporan keuangan memberitahukan bahwa kondisi keuangan perseroan terbatas tidak sehat atau mengalami kerugian maka hal tersebut merupakan alasan tidak dibayarkannya dividen pada tahun buku tersebut. Namun jika kondisi keuangan perseroan terbatas tergolong sehat bahkan mendapatkan keuntungan maka pemegang saham dapat meminta pertanggungjawaban perseroan terbatas atas tidak dibayarkannya dividen yang telah diputus untuk dibagikan. ${ }^{23}$

Peristiwa kepailitan yang berdampak pada turunnya harga saham dapat memicu terjadinya proses delisting atau penghapusan saham emiten yang tercatat di bursa. Untuk menjaga terlaksananya perdagangan efek yang teratur serta wajar dan efisien, bursa dapat melakukan penghentian sementara pelaksanaan

\footnotetext{
22 Titin Koesmia Wati, Sriyanto, dan Enis Khaerunnisa, 'Pengaruh Kebijakan Dividen Terhadap Nilai Perusahaan dengan Kebijakan Hutang Sebagai variabel Intervening Pada Perusahaan Sub Sektor Industri Barang konsumsi Periode 2011-2016' (2018) 11 (1) Sains: Jurnal Manajemen dan Bisnis 49, 50.

23 Mada Devi Kartikasari, 'Upaya Hukum Bagi Pemegang Saham dalam Penuntutan Dividen Terutang dari Perusahaan Terbatas' (2021) 4 (1) Notaire 69, 77.
} 
perdagangan bursa. ${ }^{24}$ Untuk kepentingan harta pailit, semua perbuataan hukum debitor yang dilakukan sebelum pernyataan pailit ditetapkan, yang merugikan dapat dimintakan pembatalannya. Pembatalan hanya dapat dilakukan apabila dapat dibuktikan bahwa perbuatan hukum itu merugiakan kreditor. ${ }^{25}$

Dalam proses acara kepailitan prinsip utang tersebut sangat menentukan, oleh karena tanpa adanya utang tidaklah mungkin perkara kepailitan akan bisa diperiksa. Utang merupakan raison d'etre dari kepailitan. Namun demikian, walaupun telah ada kepastian mengenai penafsiran utang tersebut dalam revisi UU Kepailitan dan PKPU, di mana utang didefinisikan dalam arti luas yang berarti telah paralel dengan konsep KUH Perdata, akan tetapi perubahan konsep utang ini menjadi terdistorsi ketika dikaitkan dengan hakikat kepailitan dalam UU Kepailitan dan PKPU yang hanya bertujuan untuk mempermudah mempailitkan subjek hukum, di mana syarat kepailitan hanya memiliki dua variabel, yaitu adanya utang yang telah jatuh tempo dan dapat ditagih kembali serta memiliki setidak-tidaknya dua kreditor. Sehingga kemudahan mempailitkan subjek hukum seakan dipermudah lagi dengan konsep utang dalam arti luas tersebut. Kelemahan UU Kepailitan dan PKPU ini sering disalahgunakan, di mana kepailitan bukan sebagai instrumen hukum untuk melakukan distribusi aset debitor akan tetapi digunakan sebagai alat untuk menagih utang atau bahkan untuk mengancam subjek hukum kendatipun tidak berkaitan dengan utang.

Dalam proses acara kepailitan konsep utang sangat menentukan, karena tanpa adanya utang tidak mungkin perkara kepailitan akan bisa diperiksa. Tanpa adanya utang tersebut maka esensi kepailitan menjadi tidak ada karena kepailitan adalah merupakan pranata hukum untuk melakukan likuidasi aset debitor untuk membayar utang-utangnya terhadap para kreditornya. Utang sebagai dasar utama untuk mempailitkan subjek hukum sangat penting sekali untuk dikaji lebih lanjut prinsip yang mendasar norma tersebut. Pembatasan jumlah nilai nominal utang sebagai dasar pengajuan permohonan kepailitan dimaksudkan untuk membatasi permohonan pailit terhadap kreditor yang memiliki jumlah utang yang sedikit (di bawah minimum) dan pembatasan skala penanganan kepailitan. Di samping itu pula, pembatasan tersebut ditujukan sebagai bentuk perlindungan hukum terhadap kreditor mayoritas dari kesewenang-wenangan kreditor minoritas. Pembatasan nilai minimum utang hanya berkaitan dengan legal standing in judicio (kewenangan untuk mengajukan perkara) sedangkan pengakuan kreditor yang di bawah nilai minimal tersebut dalam proses pembagian harta pailit sama dengan kreditor lainnya secara proporsional.

Jika dianalisis persyaratan materiil untuk mengajukan perkara kepailitan adalah sangat sederhana, yakni adanya utang yang telah jatuh tempo yang dapat ditagih, yang jatuh tempo yang belum dibayar lunas serta memiliki sekurangkurangnya dua kreditor. Adanya suatu utang akan dibuktikan oleh kreditor bahwa debitor memiliki utang yang dapat ditagih karena sudah jatuh tempo ataupun

24 Bagus Sujatmiko dan Anita Afriana, 'Perlindungan Hukum Investor Pasar Modal Akibat Kepailitan Perusahaan Terbuka Ditinjau dari Hukum Kepalitan dan Hukum Perusahaan Indonesia' (2015) 2 (2) Padjadjaran Jurnal Ilmu Hukum 250, 255.

25 Bagus Sujatmiko dan Nyulistiowati Suryanti, 'Perlindungan Hukum Bagi Investor Pada Perusahaan Terbuka yang Pailiy Ditinjau Dari Hukum Kepailitan’ (2017) 2 (1) Jurnal Bina Mulia Hukum 15, 19. 
karena dimungkinkan oleh perjanjiannya untuk dapat ditagih. Persoalan yuridis mengenai utang dalam proses pembuktian beracara kepailitan adalah utang yang bagaimana yang bisa dikategorikan utang sebagaimana diatur dalam Pasal 2 ayat (1) UU Kepailitan dan PKPU tersebut.

Dalam Pasal 1 angka 6 UU Kepailitan dan PKPU dijabarkan bahwa yang dimaksud dengan utang dalam hukum kepailitan adalah kewajiban yang dinyatakan atau dapat dinyatakan dalam jumlah uang baik dalam mata uang Indonesia maupun mata uang asing, baik secara langsung maupun yang akan timbul di kemudian hari atau kontinjen, yang timbul karena perjanjian atau undang-undang dan yang wajib dipenuhi oleh debitor dan bila tidak dipenuhi memberi hak kepada kreditor untuk mendapat pemenuhannya dari harta kekayaan debitor.

Sebenarnya dalam KUH Perdata maupun rezim hukum keperdataan tidak dikenal utang dalam arti sempit maupun utang dalam arti luas. Utang adalah utang, tidak ada utang dalam arti luas dan tidak ada utang dalam arti sempit. Utang adalah sebagaimana yang tersurat antara lain dalam Pasal $1233 \mathrm{KUH}$ Perdata. Namun di dalam praktik dan dalam wacana para ahli berkembang diskursus terminologi tersebut. Dari kedua pendapat tersebut mengenai utang, maka yang tepat adalah kelompok pendapat yang menyatakan bahwa utang dalam arti luas, karena UU Kepailitan dan PKPU merupakan penjabaran lebih khusus dari KUH Perdata, maka utang dalam UU Kepailitan dan PKPU adalah prestasi sebagaimana diatur dalam KUH Perdata. Serta berkaitan dengan prinsip debt pooling, di mana kepailitan merupakan sarana untuk melakukan distribusi aset terhadap para kreditornya dan kreditor dalam hal tidak berkaitan khusus dengan perjanjian utang piutang uang saja melainkan dalam konteks perikatan. Utang dalam kaitan dengan perikatan bisa timbul karena perjanjian dan bisa pula timbul karena undang-undang. Utang dalam perikatan yang timbul karena undangundang bisa timbul dari undang-undang saja dan bisa pula timbul dari undangundang sebagai akibat perbuatan orang. Perikatan yang lahir dari undang-undang sebagai akibat perbuatan orang bisa berupa perbuatan yang sesuai dengan undang-undang bisa pula perbuatan yang melanggar hukum.

Sedangkan maksud dari ditegaskannya bahwa utang dalam kepailitan merupakan utang yang tidak dibayar lunas adalah untuk memastikan bahwa utang yang telah dibayar akan tetapi, belum melunasi kewajiban maka utang tersebut bisa dijadikan dasar untuk mengajukan kepailitan. Penegasan ini karena sering terjadi akal-akalan dari debitor, yaitu debitor tetap melakukan pembayaran akan tetapi besarnya angsuran pembayaran tersebut masih jauh dari yang seharusnya. Hal ini juga berangkat dari pengalaman pelaksanaan peraturan kepailitan lama yaitu dalam Failissementsverordening, dimana dalam Failissementsverordening mensyaratkan bahwa debitor telah berhenti membayar utang, dan jika debitor masih membayar utang walaupun hanya sebagian dan masih jauh dari lunas, maka hal itu tidak dapat dikatakan debitor telah berhenti membayar.

Mendasarkan pada uraian diatas, maka dapat dikatakan apabila keuangan suatu PT dikatakan sehat dan sudah diputuskan dalam RUPS bahwa perusahaan tersebut akan membagikan dividen, maka lahirlah kewajiban bagi PT untuk membagikan dividen kepada pemegang sahamnya. Oleh karena muncul kewajiban 
PT terhadap pemegang saham tersebut maka dapat dikatakan bahwa PT memiliki utang kepada pemegang sahamnya sebesar dividen yang seharusnya diterima oleh pemegang saham.

\section{Akibat Hukum Dividen Perseroan Terbatas yang Tidak Dibagikan kepada Pemegang Saham dalam Kepailitan}

Secara umum, hakikat dan tujuan adanya kepailitan adalah proses yang berhubungan dengan pembagian harta kekayaan dari debitor terhadap para kreditornya. Kepailitan ini merupakan jalan keluar untuk proses pendistribusian harta kekayaan debitor yang nantinya merupakan boedel pailit secara pasti dan adil. Dikatakan secara pasti karena dalam proses kepailitan telah ditentukan langkah-langkah dan progres pembagian harta pailit secara pasti, seperti siapa saja yang merupakan kreditor dan mempunyai hak tagihan kepada si pailit, bagaimanakah mekanisme pembagian antar kreditor baik kreditor yang sejenis maupun yang tidak sejenis, serta yang lebih penting adalah masuknya pihak ketiga sebagai pihak yang independen di dalam hubungan hukum antara kreditor dan debitor. Pihak independen itu adalah kurator dan hakim pengawas. Hal ini merupakan implementasi dari prinsip debt pooling dari kepailitan.

Dimensi keadilan dari proses kepailitan adalah terletak pada dilindunginya kepentingan dari kedua belah pihak baik para kreditor pailit maupun debitor pailit. Pada prinsipnya, kepailitan bukanlah alat penekan bagi debitor untuk memenuhi kepentingan kreditor ansich. Pada prinsipnya, terdapat banyak aspekaspek hukum yang juga memperhatikan kepentingan-kepentingan debitor yang pada akhirnya untuk meminimalisasi kerugian-kerugian terhadap harta kekayaan debitor. Hal ini dapat dibuktikan antara lain dalam ketentuan masa tunggu (stay), ketentuan Penundaan Kewajiban Pembayaran Utang (PKPU), ketentuan rehabilitasi, dan lain sebagainya.

UU Kepailitan dan PKPU tidak merinci secara spesifik mengenai ketentuan yang membedakan antara kepailitan orang perorangan dan kepailitan badan hukum khususnya perseroan terbatas. Namun demikian jika dikaji lebih mendalam terdapat suatu norma yang sebenarnya hanya dapat diberlakukan terhadap kepailitan orang perorangan, akan tetapi tidak dapat diberlakukan terhadap kepailitan perseroan terbatas, demikian pula sebaliknya banyak terdapat suatu norma yang sebenarnya hanya dapat diberlakukan terhadap kepailitan perseroan terbatas akan tetapi, tidak dapat diberlakukan terhadap kepailitan orang perorangan. Seharusnya dalam UU Kepailitan dan PKPU perlu dibedakan pengaturan mengenai kepailitan yang khusus pada orang perorangan dengan kepailitan yang khusus pada perseroan terbatas.

Perseroan terbatas adalah pelaku utama dalam lalu lintas perekonomian. Sebagai pelaku utama, maka perseroan terbatas memiliki peranan yang sangat penting untuk mengembangkan sektor perekonomian. Apabila perseroan terbatas merupakan pelaku utama dalam perekonomian terjadi permasalahanpermasalahan berkaitan dengan peranannya tersebut, maka akan cukup mengguncangkan perekonomian negara. Permasalahan-permasalahan itu antara lain adalah persoalan ketidakmampuan perseroan untuk meneruskan kegiatan usahanya. Ketidakmampuan perseroan dalam meneruskan usahanya akan 
memiliki implikasi yang luas seperti kemampuan untuk membayar kembali utangutang perseroan, kemampuan untuk menghasilkan profit, serta kemampuan untuk mempertahankan eksistensi perseroan itu sendiri. Jika perseroan tidak dapat mengatasi problematika ketidakmampuan tersebut, maka akan berakibat keseimbangan neraca perusahaan yang pada akhirnya akan terjadi dimana pasiva perusahaan akan melebihi dari aktiva perusahaan. Keadaan ketidakseimbangan neraca perseroan tersebut secara teknis dapat dikatakan bahwa perseroan terbatas telah sampai pada suatu keadaan pailit.

Secara makroekonomi, kepailitan perusahaan akan sangat berpengaruh terhadap peraturan ekonomi suatu negara, yang antara lain akan mempengaruhi produktivitas terhadap barang dan jasa, jalur distribusi barang dan jasa, tingkat penerimaan pajak negara, bertambahnya angka pengangguran secara nasional, yang pada gilirannya akan mempengaruhi masyarakat pada tingkat konsumen paling bawah, sehingga kegiatan sektor riil akan sedikit terpengaruh olehnya. Kepailitan perseroan terbatas merupakan upaya bukan hanya sebagai upaya unruk menyelesaikan persoalan perseroan itu sendiri, melainkan juga mempunyai dimensi ekonomi sosial. Dalam teori kepailitan modern, dikatakan bahwa kepailitan yang terpenting untuk mengatur kondisi ekonomi secara keseluruhan.

Selain kepailitan terhadap perseroan terbatas, juga diperlukan suatu lembaga sebagai jalan lain dari putusan kepailitan perusahaan. Lembaga yang bisa digunakan sebagai alternatif dari kepailitan perusahaan adalah lembaga restrukturisasi perusahaan. Restrukturisasi perseroan terbatas ini jika dilakukan secara sistematis dan matang akan menguntungkan disamping terhadap perusahaan yang bersangkutan, dan juga secara luas akan memperkuat basis perekonomian. Tujuan utama dari restrukturisasi secara teoretis adalah mempertahankan perseroan selaku debitor untuk dapat terus menjalankan usahanya sebagai going concern dengan memberikan kesempatan kepada perusahaan yang memiliki utang kepada kreditor-kreditor yang telah dapat ditagih dan belum dapat membayar tetapi usahanya memilki prospek yang baik, untuk memperoleh kelonggaran waktu yang wajar dari kreditor-kreditornya itu guna melunasi utang-utangnya, baik dengan atau tanpa memperbaharui syarat-syarat perjanjian kredit, yang merupakan upaya alternatif penyelesaian utang melalui kepailitan.

Dalam kepustakaan, ada berbagai macam bentuk sebagai upaya melakukan restrukturisasi, yaitu antara lain:

a. Melakukan penjadwalan kembali pelunasan utang termasuk pemberian masa tenggang yang baru atau pemberian moratorium kepada perusahaan debitor;

b. Melakukan persyaratan kembali perjanjian utang;

c. Pengambilalihan utang, baik sebagian maupun keseluruhan oleh pihak lain yang dengan pengambilalihan itu menggantikan kedudukan debitor sebagai debitor pengganti untuk jumlah utang yang diambil alih;

d. Pengambilalihan tagihan dari satu atau lebih kreditor oleh pihak lain, baik untuk sebagian atau seluruh tagihan, dan yang dapat dilakukan baik oleh kreditor yang telah ada maupun oleh pihak ketiga, yang dengan pengambilalihan itu pihak yang mengambil alih menggantikan kedudukan kreditor yang tagihannya diambil alih untuk jumlah tagihan yang diambil alih; 
e. Melakukan pemotongan atau pengurangan utang pokok;

f. Melakukan perubahan tingkat suku bunga;

g. Melalukan pengurangan jumlah bunga dan/atau utang pokok yang tertunggak;

h. Memberikan utang baru;

i. Mengonversi utang dengan surat utang yang dapat dipindahtangankan;

j. Mengonversi utang dengan convertible bond;

k. Melakukan penggantian obligasi lama dengan obligasi baru;

1. Melakukan debt for equity swap;

m. Melakukan debt to aset swap;

n. Melakukan merger, akuisisi, atau konsolidasi;

o. Memasukkan modal baru oleh pemegang saham yang lama atau yang baru melalui penempatan langsung atau melalui bursa saham; dan

p. Penjualan aset tak produktif untuk membayar utang.

Sebelum melakukan upaya restrukturisasi ada beberapa prinsip yang harus dipertimbangkan, antara lain kecepatan penanganan, biaya yang tidak tinggi, dan struktur kapital yang rasional. Apabila proses restrukturisasi perusahaan mengalami jalan buntu, maka jalan keluarnya adalah kepailitan. Dengan demikian, pada prinsipnya kepailitan perseroan terbatas adalah upaya terakhir yang dilakukan untuk menyelesaikan problem perseroan yang berkaitan dengan kebangkrutan perseroan terbatas tersebut. Secara prinsip bahwa kepailitan bukanlah semata sebuah upaya yang mempermudah sebuah usaha baik itu milik perseorangan maupun berbentuk korporasi menjadi bangkrut, melainkan kepailitan adalah salah satu upaya untuk mengatasi kebangkrutan sebuah usaha.

Ricardo Simanjuntak menyatakan bahwa kepailitan khususnya corporate insolvency sebenarnya merupakan exit from financial distress, jadi merupakan suatu jalan keluar dari persoalan yang membelit yang secara finansial sudah tidak bisa lagi terselesaikan. ${ }^{26}$ Jadi terdapat suatu fakta bahwa telah ada suatu kewajiban secara teknis membuat perusahaan tersebut tidak mampu membayar, maka daripada ia berhubungan baik secara emosional maupun secara bisnis dengan setiap pihak-pihaknya, satu-satunya cara adalah ia akan meminta untuk dimohonkan pailit. Status permohonan pailit akan membuat harta yang tersisa akan dibagikan dan ia akan keluar kembali kemudian membuat usaha baru, kirakira itulah definisi dari bankrupt secara corporate dari beberapa textbook dari Amerika dan Inggris. ${ }^{27}$

Tri herwono menyitir pendapat Volkmar Gesner bahwa fungsi kepailitan penghukuman dalam kepailitan lambat laun akan kehilangan maknanya karena digantikan oleh fungsi sistem kompetisi sebagaimana dianut dalam teori ekonomi liberal. Kepailitan tidak lagi dilihat sebagai suatu kesalahan yang dilakukan oleh atau menjatuhkan martabat individu. Ketidakmampuan si pailit dianggap lebih disebabkan ketidakmampuannya untuk memenuhi permintaan pasar. Kepailitan dilihat sebagai suatu resiko yang tidak dapat dicegah dalam perdagangan bebas. Pailitnya debitor dianggap sebagai kontribusi fungsional terhadap reorganisasi dan

26 Ricardo Simanjuntak, Kepailitan dan Likuidasi (Studi Kasus: BPPN vs PT Muara Alas Prima) dalam Valerie Selvie Sinaga, 'Analisa Putusan Kepailitan pada Pengadilan Niaga Jakarta' (Tesis, Universitas Katolik Indonesia 2005) 30. 
stabilisasi permanen atas sistem ekonomi. Stigma corporate failure sekarang berubah menjadi corporate rescue. ${ }^{28}$

Prinsip commercial exit from financial distress dari kepailitan sekaligus juga memberikan makna bahwa kepailitan adalah merupakan solusi dari masalah penyelesaian utang debitor yang sedang mengalami kebangkrutan dan bukan sebaliknya bahwa kepailitan justru digunakan sebagai pranata hukum untuk membangkrutkan suatu usaha. Kemudahan untuk mempailitkan suatu debitor sebenarnya tidak bertentangan dengan prinsip ini sepanjang kemudahan untuk mempailitkan adalah dalam konteks penyelesaian utang karena adanya kesulitan finansial dari usaha debitor.

Prinsip commercial exit from financial distress merupakan prinsip yang ditemukan dalam kepailitan perseroan terbatas. Secara teoritis kepailitan perseroan terbatas harus dibedakan dengan kebangkrutan perseroan terbatas, pembubaran perseroan terbatas, dan likuidasi perseroan terbatas. Kebangkrutan perseroan terbatas adalah suatu keadaan di mana perusahaan mengalami deteriosasi adaptasi perusahaan dengan lingkungannya yang sampai membawa akibat pada rendahnya kinerja untuk jangka waktu tertentu yang berkelanjutan yang pada akhirnya menjadikan perusahaan tersebut kehilangan sumber daya dan dana yang dimiliki sebagai akibat dari gagalnya perusahaan melakukan pertukaran yang sehat antara keluaran yang dihasilkan dengan masukan baru yang harus diperoleh. ${ }^{29}$ Mirip dengan kondisi kebangkrutan perusahaan adalah apa yang dinamakan perusahaan turnaround menggambarkan situasi di mana suatu perusahaan mengalami gangguan karena kritis cashflow atau krisis laba. Meskipun demikian, definisi turnaround yang dimaksud di sini mempunyai arti yang lebih luas di mana perusahaan sering kali menunjukkan tanda-tanda atau gejala kegagalan jauh sebelum adanya krisis, mirip dengan orang yang sakit pada awalnya menunjukkan tanda-tanda akan sakit.

Adapun pembubaran perseroan terbatas (winding up) adalah merupakan suatu langkah hukum yang diambil terhadap suatu badan hukum perseroan terbatas atas alasan-alasan hukum tertentu, antara lain jangka waktu berdiri dari perseroan terbatas tersebut telah berakhir ataupun alasan-alasan hukum maupun alasan komersial yang mengharuskan badan hukum tersebut dibubarkan, baik melalui RUPS dan/atau melibatkan peran pengadilan negeri di mana kemudian untuk melakukan pengurusan dan pemberesan harta badan hukum dalam likuidasi tersebut diangkatlah tim likuidator yang bertanggungjawab kepada RUPS atau otoritas yang menaungi usaha yang dijalankan oleh badan hukum tersebut. Munir Fuady menyatakan bahwa pembubaran perusahaan adalah suatu tindakan yang menyebabkan perusahaan berhenti eksistensinya dan tidak lagi menjalankan bisnis untuk selama-lamanya, diikuti dengan proses administrasinya berupa pemberitahuan, pengumuman, dan pemutusan hubungan kerja dengan karyawannya. Bubarnya perusahaan ini baik dengan proses likuidasi secara

28 Tri Herwono, Sekilas Catatan tentang Hukum Kepailitan dalam Valerie Selvie Sinaga, 'Analisa Putusan Kepailitan pada Pengadilan Niaga Jakarta' (Tesis, Universitas Katolik Indonesia 2005) 218-219.

29 Suwarsono Muhammad, Strategi Penyehatan Perusahan: Generik dan Kontekstual (cet. 1, Ekonisia 2001) 5. 
keseluruhan (dengan dilakukan pemberesan) ataupun dengan proses likuidasi tanpa proses pemberesan sama sekali. 30

Dari teori dan ketentuan pembubaran dan likuidasi perseroan terbatas, maka terdapat perbedaan antara pembubaran dengan likuidasi. Likuidasi merupakan tindakan atau langkah pemberesan aset. Sedangkan pemberesan aset merupakan langkah yang dilakukan tidak saja terhadap badan hukum yang telah dibubarkan di luar kepailitan tetapi juga merupakan langkah pemberesan aset yang dilakukan terhadap debitor yang telah dinyatakan pailit. Hanya terjadi perbedaan pengaturan norma antara likuidasi dalam pembubaran perseroan terbatas secara umum dengan likuidasi dalam kepailitan. Likuidasi dalam pembubaran perseroan terbatas secara umum dilakukan oleh likuidator yang tunduk pada UUPT, sedangkan likuidasi dalam kepailitan dilakukan oleh kurator yang tunduk pada UU Kepailitan dan PKPU.

Disamping perbedaan tersebut, ada benang merah antara likuidasi dalam kepailitan dengan likuidasi dalam pembubaran perseroan terbatas secara umum. Benang merah tersebut seperti diungkapkan oleh Ricardo Simanjuntak bahwa dalam melaksanakan misi tersebut, maka dalam proses kepailitan diangkat seorang atau lebih kurator untuk melakukan pengurusan dan pemberesan (likuidasi) terhadap harta pailit yang telah terlebih dahulu diletakkan dalam status sita umum dan begitu juga segera setelah pembubaran perseroan diangkatlah likuidator atau tim likuidator untuk melakukan pemberesan (likuidasi) terhadap harta-harta dalam likuidasi. Artinya seluruh tindakan dari kurator maupun likuidator tersebut adalah dalam upaya untuk melakukan maksimalisasi jumlah dan nilai aset yang ada untuk segera dijual di mana hasil dari penjualan aset tersebut akan dibagikan kepada setiap kreditor dari perusahaan yang dipailitkan ataupun di bubarkan tersebut secara prorata.

Dalam hukum perseroan terbatas di Indonesia, pembubaran perseroan terbatas merupakan pranata hukum yang diatur dalam Pasal 142 UUPT. Prinsip kepailitan dan perspektif ini merupakan pranata hukum terakhir bagi penyelesaian utang-utang perseroan yang sudah tidak mampu lagi terbayar, setelah terlebih dahulu diupayakan solusi-solusi lain sebagai akibat dari kesulitan keuangan perusahaan. Sedangkan jika dikaji dari kepentingan kreditor maka kepailitan adalah upaya untuk mengatur pelaksanaan lebih lanjut dari pendistribusian aset perseroan guna membayar utang-utang perseroan, sebagaimana diatur dalam Pasal 1131 dan 1132 KUH Perdata. Kedua pasal ini saling melengkapi bahwa meskipun seluruh kreditor konkuren berhak terhadap pelunasan tagihannya dari setiap harta debitornya, akan tetapi masing-masing kreditor tidak dibenarkan oleh hukum untuk saling beradu cepat ataupun berebut kuat untuk menguasai ataupun mengambil alih harta-harta dari debitor tersebut dalam rangka mendapat pelunasan yang lebih besar, karena seluruh harta-harta debitor tersebut demi hukum harus dibagikan secara prorata parte kepada seluruh kreditor konkuren yang ada oleh kurator.

Prinsip comercial exit from financial distress tidak dianut oleh ketentuan kepailitan di Indonesia. Prinsip yang dianut dalam UU Kepailitan dan PKPU adalah

30 Munir Fuady, Hukum Perusahaan dalam Paradigma Hukum Bisnis (cet. 1, Citra Aditya Bhakti 2002) 178. 
kemudahan untuk mempailitkan subjek hukum yang berkaitan dengan debt collective proceeding. Kemudahan dalam mempailitkan suatu badan hukum bukan dalam konteks untuk mempercepat proses kepailitan terhadap badan hukum yang memang sudah seharusnya demikian. Proposisi ini terlihat dari ditentukannya syarat materiil untuk mempailitkan subjek hukum, yaitu mempunyai dua atau lebih kreditor serta salah satu utangnya telah jatuh tempo dan dapat ditagih. Prinsip kemudahan mempailitkan tersebut bahkan ditambah lagi dengan ketentuan pembuktian yang sederhana.

Padahal pada satu sisi, kepailitan adalah merupakan satu pranata hukum yang harus paralel dengan pranata pembubaran perseroan terbatas sebagaimana diatur dalam UUPT dan bukan ketentuan yang terpisah apalagi saling tidak sinkron di antara keduanya. Akan tetapi, hal ini tidak sinkron dalam peraturan perundang-undangan. Terdapat satu hal lagi yang mendukung kemudahan syarat mempailitkan suatu perseroan terbatas, yaitu makna utang. Dalam UU Kepailitan dan PKPU lebih ditegaskan lagi bahwa yang dimaksud dengan utang adalah kewajiban yang dinyatakan atau dapat dinyatakan dalam jumlah uang baik dalam mata uang Indonesia maupun mata uang asing, baik secara langsung maupun yang akan timbul di kemudian hari, yang timbul karena perjanjian atau undangundang dan yang wajib dipenuhi oleh debitor dan bila tidak dipenuhi memberi hak kepada kreditor untuk mendapat pemenuhannya dari harta kekayaan debitor. Konsep pengertian utang dalam UU Kepailitan dan PKPU menganut arti utang sebagaimana dalam KUH Perdata. Konsep utang dalam arti luas ini mempunyai implikasi yang lebih jauh dalam kepailitan suatu perseroan ini. Hal ini karena segala bentuk kewajiban prestasi dianggap sebagai utang perseroan, dan bahkan dividen yang belum dibagikan kepada pemegang saham bisa dianggap sebagai utang perseroan yang mana utang tersebut dapat ditagihkan ke perseroan terbatas dengan menggunakan pranata hukum kepailitan.

Dividen yang belum dibagikan kepada pemegang saham bisa dianggap sebagai utang perseroan, yang mana utang tersebut dapat ditagihkan ke perseroan. Akibatnya adalah perseroan yang belum membagikan dividen kepada para pemegang saham dapat dipailitkan oleh pemegang saham dengan berlandaskan pada dividen yang dianggap sebagai utang. Hal tersebut dapat terjadi dikarenakan konsep pengertian utang dalam UU Kepailitan dan PKPU menganut arti utang sebagaimana dalam KUH Perdata, yaitu utang dalam arti luas sehingga mempunyai implikasi yang lebih jauh dalam kepailitan perseroan. Artinya, segala bentuk kewajiban prestasi dianggap sebagai utang perseroan.

Permohonan kepailitan dapat dikabulkan dengan dipenuhinya syarat kepailitan seperti yang ada dalam Pasal 2 ayat (1) UU Kepailitan dan PKPU yaitu adanya utang yang telah jatuh tempo yang dapat ditagih, yang jatuh tempo yang belum dibayar lunas serta memiliki sekurang-kurangnya dua kreditor, dengan pembuktian sederhana. Syarat utang tersebut dapat dipenuhi melalui dividen yang belum dibagikan kepada pemegang saham sebagai utang perseroan terhadap pemegang saham, sehingga nantinya pemegang saham dapat menggunakan hal tersebut sebagai cara untuk mempailitkan perseroan. Meskipun jika dilihat antara aktiva dan pasiva, perseroan memiliki aktiva yang lebih besar daripada pasiva seperti yang terjadi dalam kepailitan PT Asuransi Jiwa Manulife Indonesia. 


\section{PENUTUP}

Berdasarkan uraian diatas, maka dapat disimpulkan sebagai berikut: pertama, Utang dalam kepailitan merupakan utang yang tidak dibayar lunas adalah untuk memastikan bahwa utang yang telah dibayar akan tetapi, belum melunasi kewajiban maka utang tersebut bisa dijadikan dasar untuk mengajukan kepailitan. Penegasan ini karena sering terjadi akal-akalan dari debitor, yaitu debitor tetap melakukan pembayaran akan tetapi besarnya angsuran pembayaran tersebut masih jauh dari yang seharusnya. Hal ini juga berangkat dari pengalaman pelaksanaan peraturan kepailitan lama yaitu dalam Failissementsverordening, dimana dalam Failissementsverordening mensyaratkan bahwa debitor telah berhenti membayar utang, dan jika debitor masih membayar utang walaupun hanya sebagian dan masih jauh dari lunas, maka hal itu tidak dapat dikatakan debitor telah berhenti membayar. UU Kepailitan dan PKPU menegaskan lagi bahwa yang dimaksud dengan utang adalah kewajiban yang dinyatakan atau dapat dinyatakan dalam jumlah uang baik dalam mata uang Indonesia maupun mata uang asing, baik secara langsung maupun yang akan timbul di kemudian hari, yang timbul karena perjanjian atau undang-undang dan yang wajib dipenuhi oleh debitor dan bila tidak dipenuhi memberi hak kepada kreditor untuk mendapat pemenuhannya dari harta kekayaan debitor. Konsep pengertian utang dalam UU Kepailitan dan PKPU menganut arti utang sebagaimana dalam KUH Perdata. Konsep utang dalam arti luas ini mempunyai implikasi yang lebih jauh dalam kepailitan suatu perseroan ini. Hal ini karena segala bentuk kewajiban prestasi dianggap sebagai utang perseroan, dan bahkan dividen yang belum dibagikan kepada pemegang saham bisa dianggap sebagai utang perseroan yang mana utang tersebut dapat ditagihkan ke perseroan terbatas dengan menggunakan pranata hukum kepailitan.

Kedua, dividen yang belum dibagikan kepada pemegang saham bisa dianggap sebagai utang perseroan, yang mana utang tersebut dapat ditagihkan ke perseroan. Akibatnya adalah perseroan yang belum membagikan dividen kepada para pemegang saham dapat dipailitkan oleh pemegang saham dengan berlandaskan pada dividen yang dianggap sebagai utang. Hal tersebut dapat terjadi dikarenakan konsep pengertian utang dalam UU Kepailitan dan PKPU menganut arti utang sebagaimana dalam KUH Perdata, yaitu utang dalam arti luas sehingga mempunyai implikasi yang lebih jauh dalam kepailitan perseroan. Artinya, segala bentuk kewajiban prestasi dianggap sebagai utang perseroan. Permohonan kepailitan dapat dikabulkan dengan dipenuhinya syarat kepailitan seperti yang ada dalam Pasal 2 ayat (1) UU Kepailitan dan PKPU yaitu adanya utang yang telah jatuh tempo yang dapat ditagih, yang jatuh tempo yang belum dibayar lunas serta memiliki sekurang-kurangnya dua kreditor, dengan pembuktian sederhana. Syarat utang tersebut dapat dipenuhi melalui dividen yang belum dibagikan kepada pemegang saham sebagai utang perseroan terhadap pemegang saham, sehingga nantinya pemegang saham dapat menggunakan hal tersebut sebagai cara untuk memailitkan perseroan. Berdasarkan uraian di atas, maka dapat diberikan saran sebagai berikut: pertama, pengertian utang dalam KUH Perdata dan UU Kepailitan dan PKPU sudah ada keselarasan, namun karena pengertian utang yang luas tersebut, ditambah dengan mudahnya syarat pailit 
dipenuhi membuat perseroan yang mempunyai aktiva lebih besar daripada pasiva namun memiliki utang dalam bentuk dividen yang belum dibagikan kepada pemegang saham membuat perseroan tersebut dapat dengan mudah dipailitkan. Sehingga akan lebih baik jika UU Kepailitan dan PKPU memasukkan klausula mengenai jumlah minimal utang sebagai syarat memailitkan perseroan. Kedua, klausula jumlah minimal utang yang dapat diajukan untuk mempailitkan perseroan menjadi suatu hal yang penting jika ditinjau dari UU Kepailitan dan PKPU, hal tersebut karena dengan adanya pembatasan minimal utang, maka tidak sembarang perseroan dapat diajukan permohonan pailit. Pailit hanya dapat ditempuh apabila perseroan memang sudah tidak mampu lagi membayar utangutangnya dan diperkirakan memang tidak dapat menjalankan usahanya lagi karena tidak memiliki prospek yang baik ke depannya.

\section{DAFTAR REFERENSI}

\section{Buku}

Agus S, Manajemen Keuangan Teori dan Aplikasi (ed. 4, BPFE 2008).

Brigham EF dan Houston JF, Dasar-dasar Manajemen Keuangan (ed. 10, Salemba Empat 2006).

Fuady M, Hukum Perusahaan dalam Paradigma Hukum Bisnis (cet. 1, Citra Aditya Bhakti 2002).

Harahap MY, Hukum Perseroan Terbatas (cet. 1, Sinar Grafika 2016).

Muhammad S, Strategi Penyehatan Perusahan: Generik dan Kontekstual (cet. 1, Ekonisia 2001).

Mulyawan S, Manajemen Keuangan (cet. 1, Pustaka Setia 2015).

Sinaga S, Hukum Kepailitan Indonesia (cet.1, Tata Nusa 2012).

\section{Jurnal}

Brigham dan Houston, terdapat dalam Megawati dan Rahmi Oktanina, 'Pengaruh Pengumuman Dividen Terhadap Abnormal Return Saham Sebelum dan Sesudah Ex-Dividen Pada Perusahaan yang Terdaftar di BEI' (2015) 4 (2) Jurnal Kajian Manajemen Bisnis.

Damayanti R, Marwati FS, dan Widayanti R, 'Analisa Kebijakan Dividen Berdasarkan Teori Lintner' (2017) 1 (2) Agregat: Jurnal Ekonomi dan Bisnis.

Destriana N, 'Analisis Empiris Faktor-Faktor yang Mempengaruhi Kebijakan Dividen' (2016) 18 (1) Jurnal Bisnis dan Akuntansi.

Devi AAAMV, Suardikha IMS, dan Budiasih IGAN, 'Pengaruh Profitabilitas Pada Kebijakan Dividen dengan Likuiditas dan Kepemilikan Manajerial Sebagai Variabel Pemoderasi' (2014) 3 (12) E-Jurnal Ekonomi dan Bisnis Universitas Udayana.

Dewi N, 'Penentuan Kebijakan Dividen (Dividend Policy) Dalam Praktik Perusahaan' (2010) 7 (1) Jurnal Ekonomi dan Bisnis. 
Haryanto MYD, 'Pengaruh Faktor-Faktor Keuangan Perusahaan Terhadap Kebijakan Dividen' (2015) 5 (1) Jurnal Ekonomi \& Pembangunan Optimum.

Kartikasari MD, 'Upaya Hukum Bagi Pemegang Saham dalam Penuntutan Dividen Terutang dari Perusahaan Terbatas' (2021) 4 (1) Notaire.

Permatasari P, 'Perlindungan Hukum Pemegang Saham Minoritas Perusahaan Terbuka Akibat Putusan Pailit' (2014) 1 (2) Salam; Jurnal Filsafat dan Budaya Hukum.

Purbandari, Tanggung Jawab Hukum Perseroan Terbatas (PT) yang Dinyatakan Pailit' (2014) 1 (1) E-Journal Widya Yustisia.

Retno MEL dan Permatasari P, 'Studi Terhadap Pembagian Dividen dan Dampaknya terhadap Harga Saham Perusahaan-Perusahaan yang Terdaftar di Bursa Efek Indonesia Periode 2011-2014' (2016) 2 (1) Jurnal Ilmiah Akuntansi Fakultas Ekonomi.

Samrotun YC, 'Kebijakan Dividen dan Faktor-Faktor yang Mempengaruhinya' (2015) 13 (1) Jurnal Paradigma.

Silalahi R dan Purba O, 'Peran dan Wewenang Kurator dalam Kepailitan Perseroan Terbatas' (2020) 1 (2) Jurnal Retenrum.

Sujatmiko B dan Afriana A, 'Perlindungan Hukum Investor Pasar Modal Akibat Kepailitan Perusahaan Terbuka Ditinjau dari Hukum Kepalitan dan Hukum Perusahaan Indonesia' (2015) 2 (2) Padjadjaran Jurnal Ilmu Hukum.

Sujatmiko B dan Suryanti N, 'Perlindungan Hukum Bagi Investor Pada Perusahaan Terbuka yang Pailiy Ditinjau Dari Hukum Kepailitan' (2017) 2 (1) Jurnal Bina Mulia Hukum.

Wati TK, Sriyanto, dan Khaerunnisa E, 'Pengaruh Kebijakan Dividen Terhadap Nilai Perusahaan dengan Kebijakan Hutang Sebagai variabel Intervening Pada Perusahaan Sub Sektor Industri Barang konsumsi Periode 2011-2016' (2018) 11 (1) Sains: Jurnal Manajemen dan Bisnis.

\section{Tesis}

Herwono T, Sekilas Catatan tentang Hukum Kepailitan dalam Valerie Selvie Sinaga, 'Analisa Putusan Kepailitan pada Pengadilan Niaga Jakarta' (Tesis, Universitas Katolik Indonesia 2005).

Simanjuntak R, Kepailitan dan Likuidasi (Studi Kasus: BPPN vs PT Muara Alas Prima) dalam Valerie Selvie Sinaga, 'Analisa Putusan Kepailitan pada Pengadilan Niaga Jakarta' (Tesis, Universitas Katolik Indonesia 2005).

\section{Peraturan Perundang-Undangan}

Kitab Undang-Undang Hukum Perdata.

Undang-Undang Nomor 37 Tahun 2004 tentang Kepailitan dan Penundaan Kewajiban Pembayaran Utang.

Undang-Undang Nomor 40 Tahun 2007 tentang Perseroan Terbatas.

Undang-Undang Nomor 21 Tahun 2011 tentang Otoritas Jasa Keuangan. 
